Jurnal Widya Laksana, Vol.11, No.1, Januari 2022

\title{
PEMBERDAYAAN DESA ADAT DALAM PEMBANGUNAN PARIWISATA UNTUK MEWUJUDKAN PERTUMBUHAN EKONOMI INKLUSIF KOMUNITAS KRAMA
}

\author{
Ni Ketut Sari Adnyani ${ }^{1}$, Ni Komang Febrinayanti Dantes ${ }^{2}$ \\ 1,2Jurusan Hukum dan Kewarganegaraan, Universitas Pendidikan Ganesha \\ e-mail: niktsariadnyani@gmail.com,febrinayanti.dantes@undiksha.ac.id
}

\begin{abstract}
Abstrak
Studi ini bertujuan untuk mengkaji pengaturan pengelolaan pariwisata dan penyerapan tenaga kerja lokal dengan pemberdayaan desa adat dalam pembangunan pariwisata di Provinsi Bali. Jenis program PKM hukum normatif, yaitu program PKM hukum yang didasarkan pada bahan hukum primer dan sekunder. Pendekatan program PKM ini menggunakan pendekatan peraturan perundang-undangan, pendekatan filosofis dan pendekatan sejarah, subjek sasaran adalah prajuru Desa Adat dan karma Desa Adat Ambengan, Kecamatan Sukasada, Kabupaten Buleleng, Provinsi Bali. Teknik analisa bahan hukum menggunakan teknik hermeneutika hukum. Hasil program PKM menunjukkan bahwa urgensi pengaturan penyerapan tenaga kerja lokal dari krama desa adat mencerminkan upaya perwujudan pertumbuhan ekonomi inklusif bagi komunitas krama desa adat di Provinsi Bali.Pemberdayaan desa adat tidak memberi tekanan pada pengusaha pariwisata dalam kebijakan penerimaan tenaga kerja lokal. Kombinasi lintas sektor yang diterapkan Pemerintah Daerah Provinsi Bali menjembatani kebutuhan pertumbuhan ekonomi inklusif berupa penyediaan lapangan pekerjaan dan fasilitas pelatihan maupun pendidikan magang sebelum direkrut sebagai tenaga kerja di masing-masing daerah di Provinsi Bali. Hasil program PKM ini signifikan dengan pemberdayaan desa adat dalam mewujudkan pertumbuhan ekonomi inklusif komunitas krama desa adat di Provinsi Bali.
\end{abstract}

Kata kunci: desa adat, ekonomi, inklusif, pariwisata, pemberdayaan

\begin{abstract}
This study aims to examine the regulation of tourism management and absorption of local workers by empowering traditional villages in tourism development in Bali Province. The type of normative legal PKM program is the legal PKM program based on primary and secondary legal materials. The PKM program approach uses a statutory approach, a philosophical approach and a historical approach, the target subject is the traditional village prajuru and the karma of the Ambengan Traditional Village, Sukasada District, Buleleng Regency, Bali Province. The technique of analyzing legal materials uses legal hermeneutic techniques. The results of the PKM program show that the urgency of regulating the absorption of local labor from adat village krama
\end{abstract}


reflects the effort to realize inclusive economic growth for the adat desa community in Bali Province. The cross-sectoral combination implemented by the Provincial Government of Bali bridges the need for inclusive economic growth in the form of providing job opportunities and training facilities as well as apprenticeship education before being recruited as workers in each region in Bali Province. The results of this PKM program are significant with the empowerment of traditional villages in realizing inclusive economic growth of the adat village krama community in the Province of Bali.

Keywords: traditional village, economy, inclusive, tourism, empowerment

\section{PENDAHULUAN}

Konstitusi Negara Republik Indonesia memuat pemberdayaan tentang Kesatuan Masyarakat Hukum Adat (selanjutnya disebut $\mathrm{KMHA}$ ) berdasarkan Pasal 18B Ayat (2) Undang-Undang Dasar Negara Republik Indonesia 1945 (Indonesia, 1945) (selanjutnya dikenal dengan istilah UUD NRI Tahun 1945). Tujuan hukum pemberdayaan hak KMHA, (Dahlan, 2018). Sepaham dengan itu, (Sumardjono, 2008), berpendapat Negara memperoleh hak menguasai dalam kedudukannya sebagai wakil dari seluruh rakyat. Hubungan yang dijalin antara Negara dengan rakyat bukan hubungan subordinasi, tetapi hubungan yang setara. Hal yang sama dikemukakan oleh (Nurjaya, 2008), bahwa terminologi negara harus diinterpretasikan sebagai pemerintah dan rakyat bukan Negara sebagai pemerintah semata.

Mengkaji makna pemberdayaan KMHA oleh negara menurut kedua pakar hukum di atas, peneliti mengakomodasi pandangan dari Nurjaya, mewujudkan pembangunan pariwisata berkelanjutan penting memberikan pemberdayaan terhadap KMHA dengan melakukan reposisi kedudukan antara pemerintah dan rakyat, bukan bersifat subordinasi tetapi dalam hubungan yang sejajar.

Wujud timbal balik dari hubungan yang setara atau sejajar antara Negara dan KMHA, yaitu Negara melalui konstitusi memberikan justifikasi pemberdayaan KMHA. Konsekuensinya, KMHA menjadi mempunyai hak untuk menjaga dan memperkuat karakteristik yang berbeda di bidang politik, hukum, ekonomi, sosial dan institusi-institusi budaya sekaligus tetap mempertahankan hak KMHA untuk berpartisipasi.

Mewujudkan pelaksanaan hak KMHA dalam berpartisipasi, Negara memberikan pemberdayaan KMHA berdasarkan ketentuan dalam Pasal 18B ayat (2) UUD NRI Tahun 1945, memperlihatkan adanya rekognisi bersyarat (conditional recognition). Selaras dengan pemberdayaan bersyarat KMHA dalam UUD NRI Tahun 1945, mengutip pandangan (Ari Atu Dewi, 2019), terdapat sejumlah point pendukung terkait makna pemberdayaan KMHA, diantaranya, meliputi: adanya tanggung jawab Negara memberikan pemberdayaan dan penghormatan terhadap KMHA; dipenuhinya persyaratan pemberdayaan, KMHA memiliki payung hukum dalam berbagai undang- 
Jurnal Widya Laksana, Vol.11, No.1, Januari 2022

undang; dan pengaturan pemberdayaan KMHA lebih lanjut dengan undang-undang. Mencermati beberapa pesyaratan di atas, menunjukkan terdapat pembatasan undang-undang mengenai KMHA dalam menjalankan setiap rutinitasnya.

Perwujudan pemberdayaan KMHA dalam sejumlah undang-undang sebagaimana dimaksudkan oleh Ari Atu Dewi di atas, berkenaan dengan ruang lingkup kearifan lokal dan kearifan lingkungan relevan dengan tujuan pembangunan nasional. Bersinergi dengan hal tersebut, pelibatan tataran grassrout (KMHA) dalam mewujudkan pembangunan nasional dikategorikan bersifat responsive (Nonet, 2008). Implikasi dari pemberdayaan KMHA oleh Negara yang bersifat responsif tersebut, KMHA dapat memberikan kontribusi pada pembangunan politik, sosial, budaya, ekonomi, hukum, hak asasi manusia, dan tercapainya ketahanan dan keamanan nasional, (Syafrudin, 2010). Berdasarkan beragam sendi-sendi kehidupan bernegara yang menjadi prioritas pembangunan nasional di atas, terkait KMHA fokus kajian esensi sosial budaya menjadi bagian pembangunan pariwisata.

KMHA dalam pembangunan sosial budaya diberikan kedudukan yang sederajat dengan kesatuan pemerintah lainnya, seperti Kabupaten dan Kota, (Huda, 2010). Berpangkal tolak pada rujukan di atas, pada konteks ini pemberdayaan KMHA bersinergi dengan perlindungan hukum, serta pemenuhan taraf kesejahteraan KMHA, yaitu kapasitas KMHA sebagai subjek pembangunan sosial budaya berorientasi pada tujuan cita hukum (rehctsidee) Negara Indonesia. Konsekuensinya, Negara memberikan status hukum kepada KMHA beserta hak tradisionalnya dan juga hukum adat. Pemberdayaan inilah yang juga menempatkan KMHA sebagai subjek hukum, (Safitri, 2014), dan Mahkamah Konstitusi menegaskan bahwa KMHA sebagai pengemban hak dan kewajiban.

Berdasarkan kapasitasnya sebagai subjek hukum, Di daerah Bali, yang dimaksudkan KMHA adalah Desa Pakraman (sekarang dikenal dengan sebutan Desa Adat), (Sudantra, 2014). Pada Desa Adat terdapat persekutuan hukum teritorial dengan hak dan kewajibannya, (Wiryawan, I Wayan Gde, Ketut Sukawati Lanang Putra Perbawa, 2015). (Sudantra, 2018), mengungkapkan temuan hasil program PKM bahwa subyek kepemilikan hak bersama (hak komunal) KMHA adalah Desa Adat. Program PKM serupa juga telah dilakukan sebelumnya oleh (Sudantra, 2012), terkait hak dan kewajiban desa adat belum diatur secara jelas karena belum adanya norma baru yang dimuat dalam awigawig tertulis. Berdasarkan pandangan kedua pakar hukum di atas, pemberdayaan desa adat selama ini baru diatur dalam berbagai produk peraturan perundang-undangan nasional dan belum diatur dengan undang-undang yang spesifik tentang KMHA.

Pemberdayaan desa adat telah menempatkan desa adat sebagai subjek hukum dalam pembangunan nasional salah satunya di bidang pariwisata. Sektor pariwisata sebagai salah satu sektor yang berperan dalam pembangunan memberikan kontribusi 
yang besar dalam perolehan devisa dan penyerapan tenaga kerja di Provinsi Bali. Pentingnya pariwisata dalam pembangunan ekonomi inklusif dari komunitas krama desa adat di Bali sudah tidak diragukan lagi. Sebagian besar negara di belahan dunia, sejak beberapa tahun terakhir termasuk di dalam nya Provinsi Bali yang merupakan bagian dari wilayah NKRI menggarap pariwisata dengan serius dan menjadikan pariwisata sebagai sektor unggulan di dalam perolehan devisa dan pendapatan asli daerah, penciptaan lapangan kerja, maupun pemberantasan kemiskinan, (Pitana, 2009). (Dharmawan, 2012) juga menguraikan pandangannya mengenai pariwisata dengan berbagai aspek positifnya, dipandang sebagai passport to development, new kind of sugar, tool of regional development, invisible export, non-polluting industry, dan sebagainya.

Salah satu unsur penting dalam mewujudkan tujuan Negara adalah menciptakan suatu kesejahteraan kehidupan bangsa melalui terciptanya pembangunan yang terpadu dan terencana. Secara kontekstual ketentuan Pasal 33 ayat (3) UUD NRI Tahun 1945, bahwa "bumi dan air dan kekayaan alam yang terkandung didalamnya dikuasai oleh negara dan dipergunakan untuk sebesar-besarnya kemakmuran rakyat" merupakan landasan konstitusional dalam pengelolaan pariwisata. Sehingga pasal ini dapat dijadikan rujukan penegasan dari makna yang terkandung di dalamnya bahwa bumi, air dan kekayaan alam yang terkandung di dalamnya harus dikelola sedemikian rupa sehingga mampu mentransformasi masyarakat bangsa dalam mewujudkan pertumbuhan ekonomi inklusif, menjaga keseimbangan ekologi dan sosial budaya agar dapat mendatangkan kesejahteraan dan kemakmuran masyarakat yang berkelanjutan.

Makna filosofis akan pentingnya kesejahteraan mengacu pada nilai keadilan bagi seluruh rakyat Indonesia yang sifatnya mendasar berdasarkan Pancasila. Kesejahteraan dalam dimensi filsafat akan memperhatikan aspek keadilan yang menjadi tanggung jawab negara melalui produk legislasi yang dihasilkan. Oleh karena itu, pembangunan berkelanjutan yang berwawasan lingkungan hidup dilaksanakan berdasarkan kebijakan nasional yang terpadu dan menyeluruh dengan mempertimbangkan kebutuhan generasi sekarang dan generasi yang akan datang (Tianotak, 2010).

Diberlakukan Masyarakat Ekonomi ASEAN (selajutnya disebut MEA/Asean Economic Community (AEC), Indonesia sebagai salah satu Negara anggota ASEAN akan mengalami aliran bebas barang, jasa, investasi dan tenaga kerja terdidik dari dan ke masing-masing negara anggota ASEAN, (Wyasa Putra, 2012). Untuk menghadapai MEA tentunya Indonesia sebagai bagian dari komunitas ASEAN berusaha untuk mempersiapkan diri dan memanfaatkan peluang MEA, serta meningkatkan kapabilitas agar dapat bersaing dengan negara ASEAN lainnya (Indonesia, 2011).

Permasalahan yang dihadapi dalam penyerapan tenaga kerja lokal dalam bidang pariwisata terutama tejadi tehadap penyerapan tenaga kerja lokal yang berasal dari penduduk asli daerah di sektor pariwisata. Daya saing dan 
produktivitas tenaga kerja di Indonesia relatif rendah. Salah satu penyebab utamanya adalah tingkat pendidikan tenaga kerja yang masih rendah. Berdasarkan data dari Badan Pusat Statistik Provinsi Bali per Februari 2016, dari 2.332.064 tenaga kerja yang terdaftar 858.390 merupakan lulusan Sekolah Dasar ke bawah, 369.220 lulusan Sekolah Menengah Pertama, mengikuti 400.619 lulusan Sekolah Menengah Atas, dan 294.369 lulusan Sekolah Menengah Kejuruan. Hanya 129.394 lulusan Diploma dan 280.072 Sarjana. Rendahnya kualitas SDM inilah yang menjadi permasalahan bagi penyerapan tenaga kerja lokal terutama dari masyakat setempat sebagai penduduk asli daerah sektor pariwisata yang mengakibatkan menjadi kalah saing dengan tenaga kerja lokal lainnya yang berasal dari luar daerah maupun tenaga kerja asing teutama untuk bersaing dalam pasar bebas pada era MEA (Bali, 2016).

Pemberdayaan desa adat di sektor pariwisata dalam penyerapan tenaga kerja di Provinsi Bali merupakan respon sebagai dukungan Kementerian Pariwisata dan Ekonomi Kreatif (Indonesia, 2014) dalam menciptakan lapangan kerja dan menurunkan angka pengangguran, penurunan kemiskinan nasional, serta peningkatan kesejahteraan krama (warga masyarakat) desa adat melalui sektor kepariwisataan. Namun, penyerapan tenaga kerja yang berasal dari krama desa adat tentunya harus ditunjang oleh pendidikan yang memadai.

Menindaklanjuti permasalahan di atas, berpedoman pada Global Code of Ethics for Tourism (GCET) merupakan serangkaian prinsip dasar yang menyeluruh bertujuan untuk member pedoman bagi para stakeholders seperti Pemerintah Pusat dan Daerah, krama desa adat, industri pariwisata, staf ahli di bidang pariwisata, serta wisatawan dalam membangun keparikwisataannya. Lebih lanjut ketentuan Pasl 27 ayat (2) UUD NRI Tahun 1945 menegaskan bahwa "setiap warga negara Indonesia berhak atas pekerjaan dan penghidupan yang layak bagi kemanusiaan". Selaras dengan hal tersebut, ketentuan Pasal 28D ayat (2) UUD NRI Tahun 1945 menyatakan bahwa setiap orang berhak untuk bekerja untuk mendapatkan imbalan dan perlakuan yang adil dan layak dalam hubungan kerja". Berdasarkan ketentuan pasal tersebut dapat diketahui bahwa seluruh warga Negara Indonesia memiliki kesempatan untuk bekerja mendapatkan imbalan atas pekerjaan yang dilakukan tersebut. Pasal 27 ayat (2) dan Pasal 28D ayat (2) UUD NRI Tahun 1945 ini merupakan dasar perlindungan hukum dari Negara terkait hak-hak warga Negara Indonesia untuk mendapatkan perkerjaan yang layak dan mendapatkan imbalan atas pekerjaan tersebut.

Pemaknaan Pasal 27 ayat (2) dan Pasal 28D ayat (2) UUD NRI Tahun 1945 ini diejawantahkan mengenai ketenagakerjaan dalam bidang usaha pariwisata terlihat dalam Pasal 26 huruf $g$ UU kepariwisataan secara tersirat mengatur bahwa setiap pengusaha pariwisata "berkewajiban untuk memberikan kesempatan kepada tenaga kerja lokal". Ketentuan pasal ini secara tersidar memberikan kesempatan bagi tenaga kerja yang berasal dari komunitas krama desa 
adat untuk bekerja di sektor usaha jasa pariwisata, namun dalam pasal tersebut tidak dijelaskan lebih lanjut mengenai kualitas dan kuantitas pekerja lokal yang dimaksudkan. Makna berkewajiban memiliki makna nilai-nilai moralitas yang tidak bisa diukur dengan kepastian, sedangkan wajib merupakan suatu kepastian darik nilai-nilai hukum. Maka dari itu dalam UU Kepariwisataan tidak mengatur sanksi dalam Pasal 26 dikarenakan ketentuan tersebut merupakan kaidah moral.

Pengaturan teknis yang mengatur secara lebih teperini mengenai penyerapan tenaga kerkja yang berasal dari komunitas karma desa adat yang merupakan penduduk asli daerah dalam pengelolaan usaha pariwisata adalah sebagai suatu kewajiban bagi setiap pelaku usaha tidak ditemukan pengaturannya dalam peraturan yang terkait dengan pengelolaan jasa usaha pariwisata baik di tingkat peraturan perundang-undanga maupun peraturan daerah sehingga kekosongan norma ini berakibat pada tidak ada sanksi dan tidak ada ketentuan yang secara tegas mengatur mengenai proporsi jumlah tenaga kerja lokal yang harus diserap dalam pengelolaan jasa usaha pariwisata di Provinsi Bali.

Tugas Negara dalam hal ini pemerintah sebagai pembentuk undang-undang adalah menciptakan kesejahteraan sehingga diperlukan pengaturan tekns mengenai pemberdayaan desa adat terkait peran dan pendayagunaan tenaga kerja lokal yang berasal dari komunitas krama desa adat sehingga penyerapannya pun dapat memberikan kesejahteraan dalam rangka perwujudan pertumbuhan ekonomi inklusif komunitas krama desa adat. Kajian program PKM ini merupakan konstruksi berbasis kesepakatan bersama antara krama desa adat, pakar hukum dan juga pemerintah sebagai legal drafter sehingga menarik untuk dilakukan program PKM lebih lanjut mengenai pemberdayaan desa adat dalam pembangunan pariwisata untuk mewujudkan pertumbuhan ekonomi inklusif komunitas krama.

\section{METODE}

Metode pelaksanakan pengabdian masyakat ini dilaksanakan menggunakan metode hukum (doctrinal research) bertujuan untuk memberikan eksposisinya yang bersifat sistematis mengenai suatu aturan hukum berkenaan dengan pemberdayaan desa adat pada pembangunan pariwisata dalam mewujudkan pertumbuhan ekonomi inklusif komunitas krama. Menganalisa hubungan antara aturan intrumen hukum kepariwisataan, pengelolaan pariwisata dan sebagainya yang bersinergi satu dengan yang lain, menjelaskan bagian-bagian yang sulit untuk dipahami dari suatu aturan hukum pemberdayaan desa adat dalam penyerapan tenaga kerja krama desa adat dalam pembangunan pariwisata di Provinsi Bali, tidak menutup kemungkinan juga mencakup perkembangan peraturan hukum intenasional yang mempengaruhi dinamika pembangunan hukum di Indonesia pada masa mendatang (Susanti, 2014). Pelaksanaan program PKM meliputi tahapan evaluatif dan preskriptif. Dikatakan program PKM ini bersifat evaluatif karena program PKM ini memberikan analisis mendalam 
Jurnal Widya Laksana, Vol.11, No.1, Januari 2022

tentang bentuk pemberdayaan desa adat pada pembangunan pariwisata dalam mewujudkan pertumbuhan ekonomi inklusif komunitas krama. Sifat preskriptif dari program PKM ini dapat dilihat bahwa program PKM ini juga memberikan solusi yang tepat berdasarkan prinsip-prinsip hukum, khususnya di bidang perlindungan hukum untuk mengatasi kendala dalam memberikan perlindungan kepada desa adat di Provinsi Bali.

Metode yang diterapkan dalam kegiatan ini adalah pendampingan dan konsultasi. Kedua metode ini diterapkan untuk melaksanakan program yang dirancang terjadwal dan berkelanjutan. Pendampingan dalam kegiatan ini dimaksudkan untuk mewujudkan sinergi antara masyarakat dengan Perguruan Tinggi, khususnya masyarakat Desa Adat Ambengan Kapubaten Buleleng Provinsi Bali. Pelaksanaan kegiatan dilakukan dari Mei 2021 dan konsultasi dibuka secara berkelanjutan dari masa awal pandemi hingga akhir tahun yaitu Oktober 2021. Kegiatan pendampingan berupa pertemuan dengan tokoh masyarakat dan Desa Adat Ambengan dilanjutkan dengan penyaluran bantuan kebutuhan pokok kepada masyarakat yang dilanjutkan dengan konsultasi dilakukan dengan proses sebagai berikut: Desa Adat Ambengan secara khusus dan mencari tahu persoalan sosial yang muncul sehingga faktor kelayakan pelaksanaan pengabdian kepada masyarakat Identifikasi berupa survei dilakukan pada tahap awal sebagai langkah identifikasi. Tujuannya untuk memastikan bahwa masyarakat yang berada di wilayah Desa Adat Ambengan Kecamatan Sukasada Kabupaten Buleleng banyak yang kehilangan pekerjaannya sehingga sangat sulit untuk memenuhi biaya kebutuhan seharihari.

Observasi dilakukan dengan menyimak profil dan pemetaan kemampuan masyarakat dalam mengelola persoalan sosial yang ada. Cara observasi dilakukan dengan mendatangi lokasi pelaksanaan PKM secara langsung, wawancara dengan tokoh masyarakat, komunikasi intensif dengan Jero Bendesa Adat Desa Adat Ambengan serta mencari referensi tentang profil wilayah dari berbagai aspek sosial, ekonomi dan demografi pada website resmi pemerintah Kabupaten Buleleng yaitu Potensi Pembangunan.

Realisasi berupa pendampingan dan konsultasi yang dibuka selama masa awal pandemi dan kenormalan baru dengan mengacu pada berbagi produk hukum daerah Bali yang dapat digunakan sebagai acuan dalam melaksanakan tatanan kehidupan sosial. Produk hukum daerah Bali yang dapat digunakan sebagai acuan diperoleh tim pada laman Jaringan Dokumentasi Informasi Hukum Pemerintah Provinsi Bali

Pelaksanaan program PKM ini menggunakan pendekatan peraturan perundang-undangan dan pendekatan konseptual. Pendekatan peraturan perundang-undangan digunakan untuk menelaah semua undang-undang dan regulasi yang bersangkut paut dengan 
isu hukum yang sedang diteliti dalam hal ini berkaitan dengan pemberdayaan desa adat pada pembangunan pariwisata dalam mewujudkan pertumbuhan ekonomi inklusif komunitas krama. Pendekatan peraturan perundang-undangan tersebut juga mencari ratio legis dan dasar ontologinya lahirnya peraturan perundang-undangan sehingga dapat memahami kandungan filosofis yang ada di balik undang-undang tersebut, (Marzuki, 2005). Konsep hukum adalah konsep konstruktif dan sistematis yang digunakan untuk memahami sebuah aturan, (Sidharta, 2008). Program PKM ini adalah mengkaji doktrin, asas, dan konsep dalam ilmu hukum yang berkaitan dengan masalah hukum yang menjadi pokok permasalahan yang peneliti kaji. Pemahaman akan doktrin dan pandangan tersebut menjadi pedoman bagi peneliti dalam membangun suatu argumentasi hukum dalam memecahkan isu hukum yang dihadapi.

Setelah semua bahan hukum terkumpul yang relevan dengan permasalahan, semua bahan-bahan hukum baik bahan hukum primer, bahan hukum sekunder maupun non hukum dilakukan inventarisasi, identifikasi dan klasifikasi untuk menemukan hukum sesuai dengan permasalahan yang diteliti, (Syamsudin, 2007).

Analisa bahan hukum dengan teknik hermeneutika hukum, apabila dikaitkan dengan penegakan hukum progresif tidak dapat dilepaskan dari idiologi yang mendasari perumusan dan penegakan hukum. Selanjutnya diilustrasikan dengan menggunakan teknik deskriptif analitis melalui pendekatan kualitatif terhadap bahanbahan hukum dengan mengabstraksikan peraturan perundang-undangan yang ada agar dapat menemukan norma hukum yang terkandung dalam setiap peraturan perundang-undangan terkait permasalahan pemberdayaan desa adat pada pembangunan pariwisata dalam mewujudkan pertumbuhan ekonomi inklusif komunitas karma dalam perspektif instrumen hukum nasional. Penjabaran terhadap bahan hukum yang sudah terkumpul kemudian dianalisis sesuai sifatnya, yaitu mulai dari deskriptif, evaluatif dan preskriptif berkenaan dengan fokus permasalahan dan dicari penyelesaiannya.

\section{HASIL DAN PEMBAHASAN \\ Penyerapan Tenaga Kerja Langsung di Indonesia (Triwulan I 2010- Triwulan II 2018)}

Berdasarkan studi perbandingan di luar daerah Provinsi Bali yang menjadi bagian dari wilayah Indonesia, Mengalirnya investasi asing langsung (Foreign Direct Investment/FDI) membawa konsekwensi datangnya Tenaga Kerja Asing (TKA) ke Indonesia. Salah satunya karena masuknya investasi membawa teknologi baru yang belum mampu ditangani oleh tenaga kerja lokal, baik sebagai tenaga ahli maupun operator seperti yang terjadi di kawasan industri Morowali, Sulawesi Tengah.

Badan Koordinasi Penanaman Modal (BKPM) mencatat bahwa masuknya Penanaman Modal Asing (PMA) pada triwulan II 2018 senilai Rp 204,6 triliun mampu menyerap 156.241 tenaga kerja. Sementara dari 
Penanaman Modal Dalam Negeri (PMDN) sebesar Rp 157 triliun mampu menciptakan lapangan kerja bagi 133.602 jiwa. Total, investasi langsung triwulan I tahun ini mampu menyerap 289.843 pekerja.

Secara akumulasi, sepanjang semester pertama tahun ini, investasi langsung ke Indonesia mampu menyerap 491.082 pekerja. Jumlah tersebut terdiri dari masuknya investasi asing sebanyak 253.498 pekerja dan dari investasi lokal sebanyak 237.584 pekerja. Sebagai informasi, hingga akhir Maret 2018, jumlah TKA di Indonesia mencapai 89.784 pekerja, sementara Tenaga Kerja Indonesia yang merantau ke Malaysia mencapai 728 ribu jiwa. Jadi jumlah TKA di Indonesia masih cukup kecil dibandingkan dengan TKA di Malaysia mencapai 1,78 juta pekerja.

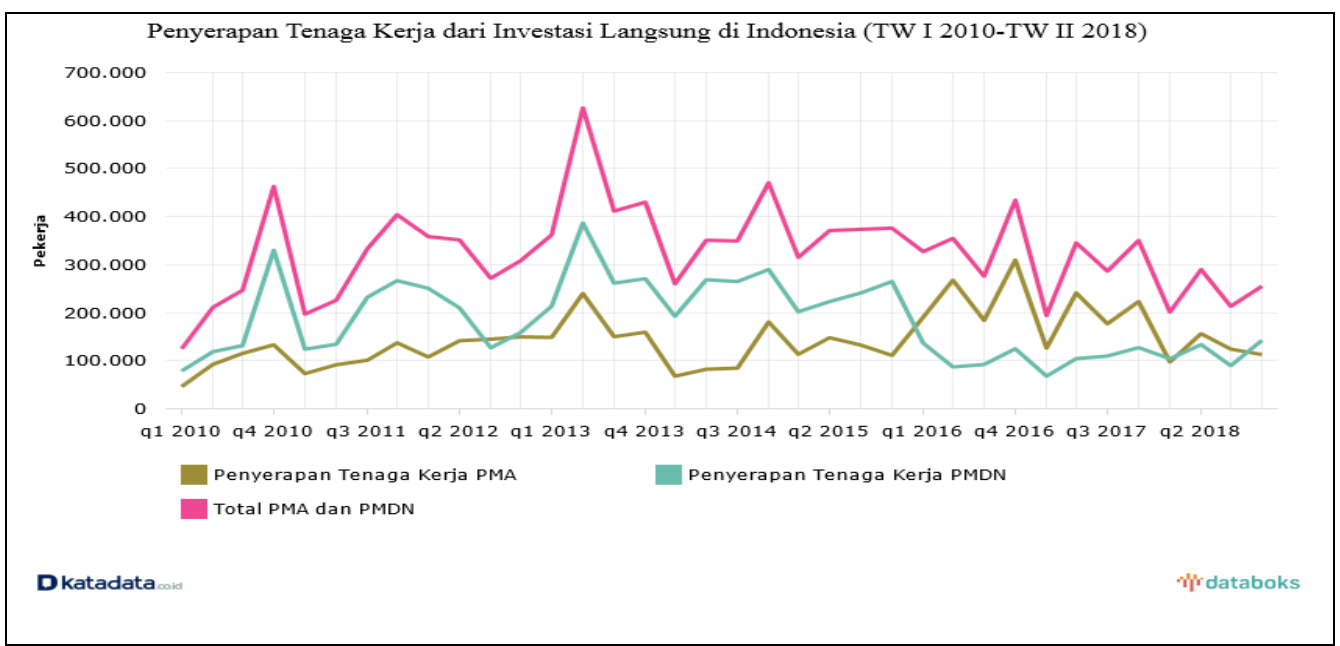

Gambar 1. Penyerapan Tenaga Kerja Langsung di Indonesia

Sumber: https://databoks.katadata.co.id/datapublish/2018/08/16/triwulan-ii-2018-investasiasingke-indonesia-serap-156-ribu-pekerja.

\section{Penyerapan Tenaga Kerja dari Komunitas Krama Desa Adat dalam Pariwisata Bali}

Sinergisitas pemberdayaan desa adat dalam pembangunan pariwisata dengan perwujudan pertumbuhan ekonomi inklusif krama desa adat, yaitu usaha jasa pariwisata sebagai sumber daya yang tidak terbatas wajib melakukan tindakan pemeliharaan terhadap sumber daya pariwisata berkenaan dengan kebudayaan. Sebagai penyangga kebudayaan Bali dan sumber daya ekonomi pariwisata tenaga kerja lokal yang direkrut dari komunitas krama desa adat memiliki pemeliharaan (memberi) dan menjaga kualitask kebudayaan sebagai sumber daya ekonomi pariwisata (Wyasa Putra, 2017). Sinergi hubungan antara tenaga kerja dengan usaha jasa pariwisata. 
Jurnal Widya Laksana, Vol.11, No.1, Januari 2022

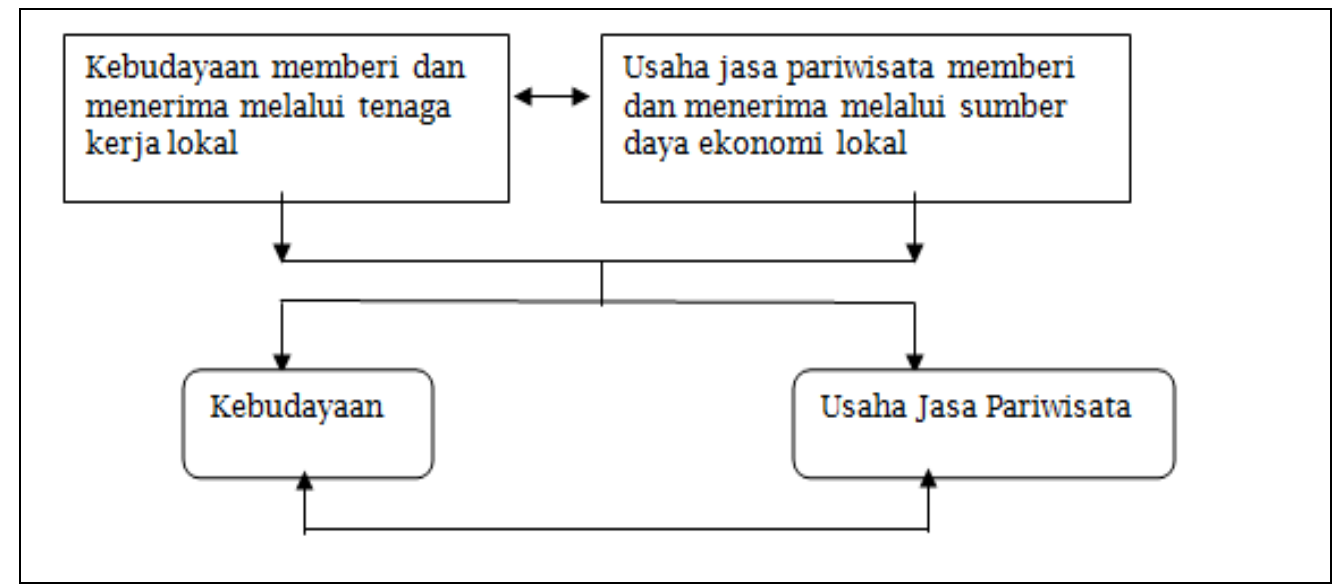

Gambar 2. Hubungan Antara Tenaga Kerja Dengan Usaha Jasa Pariwisata

$\begin{array}{rrr}\text { Gustav } & \text { Radburch } & \text { bahwa } \\ \text { hukumdalam } & \text { pencapaiannya } & \text { tidak }\end{array}$ boleh lepas dari keadilan, kepastian dan kemanfaatan, (Sidharta, 2008). Pentingnya kebijakan untuk memberikan manfaat terhadap tenaga kerja lokal di bidang usaha jasa pariwisata dalam jumlah persentase sangat penting agar hukum memiliki nilai kemanusiaan dan kemanfaatan tehadap krama desa adat akan kebahagiaan (the greatest happiness of the greates number).

\section{Dimensi Sosiologis Penyerapan Tenaga Kerja dari Komunitas Krama Desa Adat dalam Pariwisata Bali}

Penyerapan tenaga kerja yang berasal dari komunitas lokal krama desa adat di Provinsi Bali dijelaskan pada Pasal 28D ayat (2) bahwa setiap orang berhak untuk bekerja serta mendapatkan imbalan dan perlakuan yang adil dan layak dalam hubungan kerja terhadap kondisi pasar dalam negeri kebutuhan investasi berkaitan dengan kepentingan nasional untuk pengakuan desa adat terhadap kesempatan tenaga kerja di Provinsi
Bali. Optimalisasi sumber daya manusia di daerah pengembangan wisata lokal yang masih tertinggal perlu dilakukan untuk mendapatkan sumber daya manusia yang lebih berkualitas. Hal ini dimaksudkan agar masyarakat mampu bersaing untuk meningkatkan taraf hidup krama desa adat di Provinsi Bali menjadi lebih baik. Alternatif dari konsep pengelolaan pariwisata berbasis komunitas krama desa adat dengan pola padat karya lebih sesuai dengan kondisi sosial budaya komunitas krama desa adat yang dapat mendatangkan kefaedahan bagi krama desa adat (Sorinasih, 2019).

\section{Landasan Yuridis Penyerapan Tenaga Kerja dari Komunitas Krama Desa Adat dalam Pariwisata Bali}

Landasan yuridis pengaturan penyerapan tenaga kerja lokal dalam pengaturan pengelolaan usaha jasa pariwisata dapat dilihat dari konsideran mengingat dalam suatu Peraturan Perundang-undangan. Bila dicermati lebih lanjut landasan yuridis dalam pembentukan peraturan perundangundangan, antara lain: (1) Pasal 27 
ayat (2), Pasal 28D ayat (2), dan Pasal 33 ayat (1) Undang-Undang Dasar Negara Republik Indonesia Tahun 1945; Pasal 38 UU RI Nomor 39 Tahun 1999 tentang Hak Asasi Manusia ; Pasal 3 UU RI Nomor 13 Tahun 2003 tentang Keteagakerjaan (Negara Republik Indonesia, 2003); Pasal 5 dan Pasal 26 huruf g UU RI Nomor 10 Tahun 2009 tentang Kepariwisataan; Pasal 10 ayat (2) huruf b dan Pasal 12 huruf a UU RI Nomor 23 Tahun 2014 tentang Pemerintahan Daerah; Pasal 3 Peraturan Daerah Provinsi Bali Nomor 2 Tahun 2012 Tentang Kepariwisataan Budaya Bali (Bali, 2012).

\section{Pengaturan Pengakuan Desa Adat dalam Pengelolaan Pariwisata Di Provinsi Bali}

Pembangunan kepariwisataan merupakan rangkaian upaya pembangunan sektor kepariwisataan secara nasional yang berkesinambungan. Operasionalnya menempatkan desa adat sebagai titik sentral pembangunan, baik sebagai subyek pembangunan maupun sebagai objek pembangunan, (Muljadi, A. J., Warman, 2014). Pengakuan desa adat (komunitas setempat) yang berada di destinasi melalui kegiatan usaha kepariwisataan merupakan salah satu model pembangunan yang sedang mendapatkan perhatian dari berbagai kalangan dan akan menjadi agenda penting dalam proses pembangunan kepariwisataan ke depan. Prinsip pengakuan desa adat merupakan suatu proses yang tidak saja hanya mengembangkan potensi ekonomi inklusif krama desa adat di Provinsi Bali, namun juga berupaya dapat meningkatkan harkat dan martabat, pasa percaya diri dan harga dirinya serta tepeliharanya tatanan niilai budaya setempat. Konstruksi pengakuan desa adat seperti tersebut pada akhinya juga telah diadopsi sebagai suatu strategi pembangunan sosial, ekonomi, dan budaya yang diimplementasikan dalam kerangka design kepariwisataan yang berpusat pada krama desa adat yang mempunyai sasaran tidak saja menumbuhkan dan mengembangkan nilai tambah ekonomi, tetapi juga nilai tambah yang bersifat beyond economic (sosial budaya) (Sunaryo, 2013).

Perkembangan pariwisata dapat menunjang penyerapan tenaga kerja krama desa adat dalam rangka perolehan income desa adat. Pengakuan desa adat dalam pembangunan pariwisata untuk mewujudkan pertumbuhan ekonomi inklusif krama desa adat melalui kepariwisataan pada prinsipnya harus senantiasa diarahkan pada empat sasaran utama, yaitu: (1) peningkatan kapasitas, peran inisiatif desa adat sebagai subyek atau pelaku penting dalam pembangunan pariwisata; (2) peningkatan posisi dan kualitas keterlibatan atau pengakuan desa adat dalam pembangunan kepariwisataan; (3) peningkatan manfaat positif pembangunan pariwisata bagi pertumbuhan ekonomi inklusif krama desa adat; dan (4) peningkatan kemampuan krama desa adat dalam melakukan perjalanan wisata.

Penyelenggaraan

sektor kepariwisataan yang berbasis pengakuan desa adat dapat dimaknai sebagai bentuk perlindungan terhadap nilai-nilai agama, budaya yang hidup dalam masyarakat dan kelestarian 
lingkungan. Dengan pengakuan desa adat dalam pembangunan pariwisata untuk mewujudkan pertumbuhan ekonomi inklusif krama desa adat, sasaran yang hendak dicapai yaitu: pembangunan kepariwisataan yang komprehensif dan berkelanjutan, koordinasi lintas sektor, pengaturan kawasan strategis, pemberdayaan usaha mikro, kecil dan menengah di dalam dan di sekitar destinasi pariwisata, penyerapa tenaga kerja lokal, badan promosi pariwisata, asosiasi kepariwisataan, standarisasi usaha, dan kompetensi pekerja pariwisata serta pemberdayaan pekerja pariwisata melalui pelatihan sumber daya manusia.

Sumber daya manusia teutama tenaga kerja dalam pengelolaan usaha jasa pariwisata merupakan salah satu bagian yang terpenting sebagai alat untuk meningkatkan mutu dari suatu kualitas produk ditentukan oleh kualitas sumber daya manusia yang menentukan mutu dari kualitas produk pariwisata. Salah satu prosedur yang harus dilakukan yaitu penyerapan tenaga kerja yang memang berkompeten dalam bidang pariwisata.

Pemaknaan Pasal 27 ayat (2) dan Pasal 28D ayat (2) UUD NRI Tahun 1945 diejawantahkan mengenai ketenagakerjaan dalam bidang usaha jasa pariwisata terlihat dalam Pasal 26 huruf $g$ UU Kepariwisataan adalah menganggap lebih penting memberikan kesempatan kepada tenaga kerja lokal di bidang usaha jasa pariwisata. Pasal 26 huruf g UU Kepariwisataan secara tersirat mengatur bahwa setiap pengusaha pariwisata "berkewajiban untuk memberikan kesempatan bagi tenaga kerja lokal untuk bekerja di sektor usaha jasa pariwisata, namun dalam penjelasan pasal tersebut tidak dijelaskan lebih lanjut mengenai kualitas dan kuantitas pekerja lokal yang dimaksudkan.

\section{Penyerapan Tenaga Kerja Lokal pada Pengaturan Pengakuan Desa Adat dalam Pembangunan Pariwisata Di Provinsi Bali}

Pengelolaan di sektor pariwisata harus berperan sebagai prime mover dan secara interaktif terkait dengan pengembangan sektor-sektor lainnya. Pengembangan pariwisata harus diupayakan dapat melibatkan stakeholders mulai dari pemerintah, swasta hingga pengakuan desa adat setempat. Dalam konteks ini peran krama desa adat terlibat dimulai dari sektor hulu (memberikan kegiatan produksi yang ekstraktif) sampai dengan kegiatan hilir (kegiatan produksi jasa). Peningkatan peran serta pengakuan desa adat dalam pengelolaan dan pengembangan usaha jasa pariwisata menjadi salah satu hal yang harus diperhatikan dalam pelaksanaan pembangunan kepariwisataan. Dalam menyelenggarakan kegiatan pariwisata harus melibatkan krama desa adat, sehingga manfaatnya dapat dirasakan langsung oleh krama desa adat.

Hal ini menunjukkan bahwa peran jasa usaha pariwisata dalam peningkatan penyerapan tenaga kerja yang berasal dari komunitas krama desa adat setempat sangat penting agar dapat saling menguntungkan bagi usaha jasa pariwisata dan juga bagi krama desa adat di komunitas mereka melakukan usahanya. Penyerapan 
tenaga kerja lokal dilakukan elalui tahapan rekrutmen.

Pertumbuhan ekonomi inklusif komunitas krama desa adat di Provinsi Bali membutuhkan sumber daya. Sumber daya yang diperlukan adalah manusia. SDM berperan penting dalam proses pembangunan karena SDM merupakan penggerak factor-faktor produksi. Tingginya kesempatan kerja di Provinsi Bali berpengaruh terhadap pertumbuhan ekonomi inklusif, dengan demikian jumlah penduduk Provinsi Bali relatif besar menentukan laju pertumbuhan ekonominya. Kesempatan kerja yang tersedia dan kualitas tenaga kerja yang digunakan akan menentukan proses pembangunan ekonomi krama desa adat.

Pemerintah Provinsi Bali melihat masalah ketenagakerjaan sebagai salah satu bahkan sentral pembangunan nasional yang bertujuan untuk: (1) memberdayakan dan mendayagunakan tenaga kerja; (2) mewujudkan kesempatan kerja dan penyediaan lapangan pekerjaan; (3) memberikan perlindungan terhadap tenaga kerja dalam mewujudkan kesejahteraan sebagai bagian dari pertumbuhan ekonomi inklusif dan (4) meningkatkan kesejahteraan tenaga kerja dan keluarganya. Pembangunan ketenagakerjaan, pemerintah Provinsi Bali diharapkan dapat menyusun dan menetapkan perencanaan tenaga kerja. Perencanaan dimaksudkan agar dapat dijadikan dasar dan acuan dalam penyusunan kebijakan. Strategi dan implementasi program pembangunan ketenagakerjaan yang berkesinambungan

\section{KESIMPULAN}

Pengaturan pengelolaan usaha jasa pariwisata dalam penyerapan tenaga kerja lokal dari komunitas krama desa adat berdasarkan dimensi filosofis, sosiologis dan yuridis. Pemerintah Provinsi Bali menggerakkan potensi kepariwisataan dalam dinamika kehidupan lokal dengan pemberdayaan pada eksistensi desa adat dalam pembangunan pariwisata untuk mewujudkan pertumbuhan ekonomi inklusif krama desa adat. Kebijakan penyerapan tenaga kerja lokal menjadi rujukan legal drafter di tingkat Pemerintah Daerah untuk tidak hanya mengatur tentang penempatan tenaga kerja lokal semata, tetapi juga mengatur pelatihan dan pendidikan serta pemagangan penempatan tenaga kerja di Provinsi Bali.

Pemerintah Provinsi Bali penting melakukan pengkajian tehadap pemberdayaan desa adat dalam pembangunan pariwisata berkenaan penyerapan tenaga kerja lokal dalam mewujudkan pertumbuhan ekonomi inklusif krama desa adat. Penting menjalin sinergi mutual triple helix antara Pemerintah Daerah Provinsi Bali, pelaku usaha jasa pariwisata dan krama desa adat sebagai upaya transfaransi penempatan tenaga kerja serta memberikan ruang pemberdayaan desa adat dalam berpartisipasi melalui pemberdayaan krama desa adat dalam penyerapan tenaga kerja.

\section{DAFTAR PUSTAKA}

$\begin{array}{ccc}\text { Ari Atu Dewi, A. } & \text { A. I. } & \text { (2019) } \\ \begin{array}{c}\text { Penyusunan } \\ \text { Partisipatif: }\end{array} & \begin{array}{c}\text { Perda } \\ \text { Peran }\end{array} & \text { Desa }\end{array}$


Jurnal Widya Laksana, Vol.11, No.1, Januari 2022

Pakraman Dalam Pembentukan Peraturan Daerah. Denpasar, Bali: Zifatama Jawara.

Bali, B. P. S. P. (2016) 'Keadaan ketenagakerjaan Provinsi Bali Februari 2016.'

Bali, P. P. (2012) Peraturan Daerah Provinsi Bali Nomor 2 Tahun 2012 tentang Kepariwisataan Budaya Bali. Indonesia.

Dahlan, M. (2018) 'Rekognisi Hak Masyarakat Hukum Adat dalam Konstitusi"', Undang: Jurnal Hukum, 1(2), p. 194.

Dharmawan, N. K. S. (2012) 'Tourism And Environment: Toward Promoting Sustainable Development Of Tourism: A Human Rights Perspective', Indon. L. Rev, 2(23), p. 25.

Huda, N. (2010) Otonomi Daerah; Filosofi, Sejarah Perkembangan dan Problematika. Yogyakarta: Pustaka Pelajar.

Indonesia, K. ketenagakerjaan R. (2018) Penyerapan Tenaga Kerja Langsung di Indonesia (Triwulan I 2010- Triwulan II 2018). Available at: https://databoks.katadata.co.id/d atapublish/2018/08/16/triwulanii-2018-investasi-asingkeindonesia-serap-156-ribupekerja Diakses hari Jumat, 11 Maret 2021.

Indonesia, K. P. R. (2011) Perkembangan Masyarakat Ekonomi ASEAN (ASEAN ommunity in a Global ommunity of Nations).

Indonesia, K. P. R. (2014) Laporan
Kementerian Pariwisata.

Indonesia, N. R. (1945) UndangUndang Dasar Negara Republik Indonesia Tahun 1945.

Marzuki, P. M. (2005) Penelitian Hukum. Edisi Revisi. Jakarta: Kencana Prenada.

Muljadi, A. J., Warman, A. H. (2014) Kepariwisataan dan Perjalanan. Edisi Revisi. Jakarta: Raja Grafindo Persada.

Negara Republik Indonesia (2003) Undang-Undang Republik Indonesia Nomor 13 Tahun 2003 Tentang Ketenagakerjaan. Indonesia.

Nonet, P. dan P. S. (2008) Hukum Responsif. Terjemahan Raisul Muttaqien. Cet. ke-2. Bandung: Nusamedia.

Nurjaya, I. N. (2008) Pengelolaan Sumber Daya Alam dalam Perspektif Antroplogi Hukum. Jakarta: Prestasi Pustaka Publisher.

Pitana, G. dan I. K. S. D. (2009) Pengantar IImu Pariwisata. Jakarta: Andi.

Safitri, M. A. dan L. U. (2014) 'Adat Di Tangan Pemerintah Daerah". Panduan Penyusunan Produk Hukum Daerah Untuk Pengakuan Dan Perlindungan Hak Masyarakat Hukum Adat', Jurnal Efistema, 13(2), p. 7.

Sidharta, B. A. (2008) Refleksi tentang Struktur IImu Hukum, Cetakan Kedua. Bandung: Mandar Maju.

Sorinasih, N. W. (2019) Pengaturan Penyerapan Tenaga Kerja Lokal 
Jurnal Widya Laksana, Vol.11, No.1, Januari 2022

dalam Pengelolaan Usaha Jasa Pariwisata. Denpasar.

Sudantra, I. K. (2018) Pensertifikatan Tanah Adat Di Bali: Mendiagnosa Implikasi Penunjukan Desa Pakraman Sebagai Subyek Hak Komunal Atas Tanah. Denpasar, Bali.

Sudantra, I. K. dan I. W. W. (2012) Sesana Prajuru Desa Tata Laksana Pimpinan Desa Adat di Bali. Denpasar, Bali: Udayana University Press.

Sudantra, I. K. dan N. N. S. (2014) "Pengaturan Peradilan Adat dalam Awig-awig Desa Pakraman: Studi Pendahuluan tentang Eksistensi Peradilan Adat dalam Kesatuan Masyarakat Hukum Adat Desa Pakraman"', Jurnal Magister Hukum Udayana, 3(2), p. 316.

Sumardjono, M. S. W. (2008) Tanah dalam Perspektif Hak Ekonomi, Sosial, dan Budaya. Jakarta: Kompas.

Sunaryo, B. (2013) Kebijakan Pembangunan Destinasi Pariwisata Konsep dan Aplikasinya $\mathrm{Di}$ Indonesia. Yogyakarta: Gava Media.

Susanti, D. O. dan A. E. (2014) Penelitian Hukum (Legal
Research). Jakarta: Sinar Grafika.

Syafrudin, A. dan N. S. (2010) Republik Desa, Pergulatan Hukum Tradisional dan Hukum Modern dalam Desain Otonomi Desa. Bandung: Alumni.

Syamsudin, M. (2007) Operasional Penelitian Hukum. Jakarta: Raja Grafindo Persada.

Tianotak, N. (2010) 'Perlindungan Hukum atas Hak Asasi Masyarakat Adat dalam Pengelolaan Sumber Daya Hutan Di Provinsi Maluku", Jurnal Sasi, 6(4), p. 27.

Wiryawan, I Wayan Gde, Ketut Sukawati Lanang Putra Perbawa, I. W. W. (2015) "Hukum Adat Bali di Tengah Modernisasi Pembangunan dan arus Budaya Global"', Jurnal Bakti Saraswati (JBS), 4(2), p. 170.

Wyasa Putra, I. B. (2012) "'ASEAN Law"', Journal of East Asia and Intenational Law:Yijun Institute of Intenational Law, 5(2), p. 366.

Wyasa Putra, I. B. (2017) Landasan Teoritik Pengaturan Pelestarian Warisan Budaya: Bali sebagai Suatu Model. Denpasar, Bali: Udayana University Press. 